\section{$\underset{\substack{\text { hommes } \\ \text { \& migrations }}}{ }$}

\section{Hommes \& migrations}

Revue française de référence sur les dynamiques

migratoires

\section{$1320 \mid 2018$}

Au prisme de la consommation

\title{
Yves promise
}

Film allemand, 2017, de Melanie Gärtner

\section{Anaïs Vincent}

\section{(2) OpenEdition \\ 1 Journals}

\section{Édition électronique}

URL : http://journals.openedition.org/hommesmigrations/4086

DOI : ERREUR PDO dans /localdata/www-bin/Core/Core/Db/Db.class.php L.34 : SQLSTATE[HY000]

[2006] MySQL server has gone away

ISSN : 2262-3353

\section{Éditeur}

Musée national de l'histoire de l'immigration

\section{Édition imprimée}

Date de publication : 1 janvier 2018

Pagination : 160

ISBN : 978-2-919040-40-7

ISSN : $1142-852 X$

\section{Référence électronique}

Anaïs Vincent, « Yves promise », Hommes \& migrations [En ligne], 1320 | 2018, mis en ligne le 01 janvier 2018, consulté le 08 janvier 2021. URL : http://journals.openedition.org/hommesmigrations/4086 ; DOI : https://doi.org/ERREUR PDO dans /localdata/www-bin/Core/Core/Db/Db.class.php L.34 : SQLSTATE[HY000] [2006] MySQL server has gone away 


\section{FILMS}

\section{Melanie Gärtner Yves promise}

Allemagne, 2017

Présenté tout récemment dans les salles allemandes, le nouveau documentaire de la réalisatrice, anthropologue et journaliste Melanie Gärtner, sélectionné en compétition au Festival international du film documentaire d'Amsterdam, est promis à un brillant avenir.

Spécialiste de la question de l'immigration, Melanie a rencontré Yves, le protagoniste de son nouveau documentaire, en 2010 lors du tournage de son très remarque premier film The Land in Between. Elley suivait les destins d'exilés sans papier détenus dans le centre de rétention de l'enclave de Ceuta.

Après une première expulsion, le jeune camerounais écœuré par la corruption tente à nouveau sa chance vers l'Europe, terre promise. Yves a été sur la route pendant huit longues années. La réalisatrice l'a suivi dans ses tentatives d'échapper à la précarité de son pays natal, animé par la volonté de pouvoir aider financièrement sa famille.

Yves fixe la mer, le regard plein d'espoir et de désillusion. Les vagues s'échouent sur le rivage.

Melanie le retrouve à Bilbao en Espagne vivant dans un abri de fortune sous les ponts. Au fil des rencontres, son projet prend une direction inattendue. Quelles sont les motivations profondes du migrant ? Dans son enquête, elle tente de comprendre son acharnement et ainsi, par extension, celui de centaine de milliers d'autres exilés économiques. À travers cet essai cinématographique, elle pose un regard bienveillant et attentif sur l'entêtement du jeune homme, en décidant de devenir son messager. Ainsi ira-t-elle transmettre à sa famille son message d'espoir: Yves ne veut pas encore renoncer et espère pouvoir revenir au pays avec dignité.

Elle se rend au Cameroun chez ses proches et filme leurs réactions émues alors qu'ils découvrent l'image d'Yves sur l'écran lumineux de son iPad et écoutent, attentifs, ses paroles pleines de tendresse. Elle crée ainsi un lien virtuel entre l'ici et l'ailleurs, un dialogue fictif avec le migrant et ceux restés au pays qui attendent avec impatience son retour. À travers les témoignages de la famille, elle construit un portrait fragmenté du jeune homme. En arrière-plan, elle évoque le déséquilibre des rapports Nord/Sud, la question de l'exil, de l'éloignement.

Si le dispositif filmique nous séduit par sa pertinence, on peut regretter cependant un montage un peu maladroit avec certaines longueurs dans les entretiens, donnant à l'ensemble du film un rythme légèrement bancal, malgré un sujet plein d'humanité.

Anaïs Vincent 